1 Validity of Wrist and Forehead Temperature in Temperature Screening in the General

2 Population During the Outbreak of 2019 Novel Coronavirus: a prospective real-world

3 study

5 (Validity of Wrist and Forehead Temperature in Temperature Screening in the General

6 Population During the Outbreak of COVID-19)

8 Ge Chen ${ }^{1,8}$, Jiarong Xie ${ }^{2,3,8}$, Guangli Dai ${ }^{1}$, Peijun Zheng ${ }^{4}$, Xiaqing $\mathrm{Hu}^{5}$, Hongpeng $\mathrm{Lu}^{2,3}$, Lei

$9 \mathrm{Xu}^{2,3}$, Xueqin Chen ${ }^{6} *$ Xiaomin $\mathrm{Chen}^{2,7} *$

$11{ }^{1}$ Department of Clinical Engineering, Ningbo First Hospital, Ningbo, Zhejiang Province,

12 China;

$13{ }^{2}$ Department of General Internal Medicine, Ningbo First Hospital, Ningbo, Zhejiang Province,

14 China;

$15{ }^{3}$ Department of Gastroenterology, Ningbo First Hospital, Ningbo, Zhejiang Province, China;

$16{ }^{4}$ Department of Nursing, Ningbo First Hospital, Ningbo, Zhejiang Province, China;

$17{ }^{5}$ Department of Emergency, Ningbo First Hospital, Ningbo, Zhejiang Province, China;

$18{ }^{6}$ Department of Chinese Traditional Medicine, Ningbo First Hospital, Ningbo, Zhejiang

19 Province, China;

$20{ }^{7}$ Department of Cardiology, Ningbo First Hospital, Ningbo, Zhejiang Province, China;

$21{ }^{8}$ These authors contributed equally to this work.

$22 *$ Corresponding authors

24 Abbreviations: 2019-nCoV, 2019 Novel Coronavirus; NCIT, Non-contact infrared

25 thermometer; IRTT, infrared tympanic thermometers; ROC, receiver-operator characteristic. 
medRxiv preprint doi: https://doi.org/10.1101/2020.03.02.20030148; this version posted March 6, 2020. The copyright holder for this preprint

(which was not certified by peer review) is the author/funder, who has granted medRxiv a license to display the preprint in perpetuity.

All rights reserved. No reuse allowed without permission.

26

27 Key words: 2019 Novel Coronavirus; wrist temperature; non-contact infrared thermometer;

28 
medRxiv preprint doi: https://doi.org/10.1101/2020.03.02.20030148; this version posted March 6, 2020. The copyright holder for this preprint (which was not certified by peer review) is the author/funder, who has granted medRxiv a license to display the preprint in perpetuity.

All rights reserved. No reuse allowed without permission.

\section{Abstract $^{\circ}$}

30 Aims: Temperature screening is important in the population during the outbreak of 2019

31 Novel Coronavirus (COVID-19). This study aimed to compare the accuracy and precision of

32 wrist and forehead temperature with tympanic temperature under different circumstances.

33 Methods: We performed a prospective observational study in a real-life population. We

34 consecutively collected wrist and forehead temperatures in Celsius $\left({ }^{\circ} \mathrm{C}\right)$ using a non-contact

35 infrared thermometer (NCIT). We also measured the tympanic temperature using a tympanic

36 thermometers (IRTT) and defined fever as a tympanic temperature $\geq 37.3^{\circ} \mathrm{C}$.

37 Results: We enrolled a total of 528 participants including 261 indoor and 267 outdoor

38 participants. We divided outdoor participants into four types according to their means of

39 transportation to the hospital as walk, bicycle, electric vehicle, car, and inside the car. Under

40 different circumstance, the mean difference ranged from -1.72 to $-0.56^{\circ} \mathrm{C}$ in different groups

41 for the forehead measurements, and -0.96 to $-0.61^{\circ} \mathrm{C}$ for the wrist measurements. Both

42 measurements had high fever screening abilities in inpatients (wrist: AUC 0.790; 95\% CI:

$43 \quad 0.725-0.854, P<0.001$; forehead: AUC 0.816; 95\% CI: $0.757-0.876, P<0.001)$. The cut-off

44 value of wrist measurement for detecting tympanic temperature $\geq 37.3^{\circ} \mathrm{C}$ was $36.2^{\circ} \mathrm{C}$ with a

$4586.4 \%$ sensitivity and a $67.0 \%$ specificity, and the best threshold of forehead measurement

46 was also $36.2^{\circ} \mathrm{C}$ with a $93.2 \%$ sensitivity and a $60.0 \%$ specificity.

47 Conclusions: Wrist measurement is more stable than forehead measurement under different

48 circumstance. Both measurements have great fever screening abilities for indoor patients. The

49 cut-off value of both measurements was $36.2^{\circ} \mathrm{C}$. (ClinicalTrials.gov number: NCT04274621) 
medRxiv preprint doi: https://doi.org/10.1101/2020.03.02.20030148; this version posted March 6, 2020. The copyright holder for this preprint

\section{Introduction}

52 The outbreaks of 2019 novel coronavirus COVID-19 (previously known as 2019-nCoV)

53 has attracted global attention, due to its strong transmission ability and certain fatality $(1,2)$.

54 Some studies reported that fever, fatigue and dry cough are common symptoms of

55 COVID-19 patients $(3,4)$, and $43.8 \%$ of the patients showed fever before admission with it

56 largely being the first symptom (5). Therefore, temperature screening in the high-risk

57 population is important for early identification of COVID-19 infection and thereby reducing

58 the risk of cross infection.

59 During the epidemic, infrared tympanic thermometers (IRTT) and non-contact infrared

60 thermometer (NCIT) are being applied to temperature screening in the general population (6).

61 As a screening tool, it is quick for mass screening and allows a faster triage (7). However, we

62 need to consume a lot of disposable plastic covers when we use IRTT. It may increase the

63 financial burden in the widespread use of population screening. Furthermore, indirect

64 contacts with infected individuals may increase the risk of cross infection. NCIT meets the

65 clinical requirements for mass screening in terms of detection efficiency, safety and

66 cost-performance. Besides, it takes less time than IRTT. Forehead is one of the key targets of

67 thermography. However, forehead temperature is affected by physiological and

68 environmental conditions (8). It should be measured in a relatively temperature-controlled

69 environment. A previous study suggested to acclimate to the indoor temperature for at least

7010 min for those who were exposed to the cold before taking body temperature readings (8).

71 However, it is not practical for mass screening in winter during the outbreak of COVID-19.

72 Wrist temperature in this outbreak is under consideration. Before testing, they just need

73 to roll up their sleeves at $10 \mathrm{~cm}$ above the palmar side of the wrist. Considering this area is

74 covered with clothing, the wrist temperatures may keep stable. Previous study showed

75 wearable devices (WD) on the wrist were applied in temperature monitoring in clinical 
76 practice (9). It brings a challenge whether it can be used as an accurate, safe and 77 cost-effective screening tool in this outbreak.

78 In this study, we explored the accuracy and advantages of wrist temperature

79 measurement in a real-life population in different environments and conditions. We aimed to

80 find the thresholds of this key technique for diagnosis of fever. It may assist to improve the 81 standardization of both practical use and performance, especially indispensable in the 82 pandemic 2019-nCoV situation.

83

84 


\section{Materials and Methods}

\section{Study population}

87 This was a prospective observational study in a real-life population. We consecutively 88 enrolled a total of 572 participants at Ningbo First Hospital in China in this study (Figure 1).

89 The exclusion criteria included: (i) Age $\leq 18$ years $(n=6)$; (ii) Wearing hearing aid, or

90 having a cerumen $(n=7)$; (iii) Participants with soft tissue infection or trauma $(n=3)$; (iv)

91 Missing data of wrist, forehead, and tympanic temperature $(n=4)$; and (v) Participants whose

92 forehead temperature measurements showed "low" $(n=23)$. We finally enrolled 528 eligible

93 participants for the final analysis, including 261 indoor and 267 outdoor participants. The 261

94 indoor participants were from the fever clinic and emergency department, and the 267

95 outdoor participants included patients and accompanying family members. The data of indoor

96 participants were collected consecutively between February 14th and February 20th, 2020.

97 The data of outdoor participants were collected on February 14th, 15th, 17th, 2020.

98 Temperature readings were taken by trained and experienced nurses. Each participant was 99 measured for wrist, forehead, and tympanic temperature twice. The temperatures were 100 recorded by mean wrist temperature, forehead, and tympanic temperature, respectively. Data 101 regarding age, gender, transportation, occupation, and temperature were recorded 102 immediately by the nurse to pre-printed files.

103 The study was approved by Ningbo First Hospital Ethics Committee. All participants 104 were asked verbally. They gave their oral informed consent in this study. The study was 105 registered in ClinicalTrials.gov with identifier number: NCT04274621.

\section{Assessment of environment}

108 Indoor patients at the fever clinic and emergency department were those who has been 109 indoors for at least a few minutes. The outdoor participants were divided into four type 
medRxiv preprint doi: https://doi.org/10.1101/2020.03.02.20030148; this version posted March 6, 2020. The copyright holder for this preprint

110 according to their means of transportation to the hospital as walk, bicycle/electric vehicle, car,

111 and inside the car.

112

\section{Measurement of temperature}

114 Tympanic temperature was measured using IRTT (Braun ThermoScan PRO 6000). Wrist 115 and forehead temperature were measured using NCIT. The NCIT was ranged $32.0-42.9^{\circ} \mathrm{C}$.

116 The accuracy was $\pm 0.2^{\circ} \mathrm{C}$. NCIT measurements were taken following the manufacturer's

117 instructions in the mid-forehead and a region at $10 \mathrm{~cm}$ above the palmar side of the wrist.

118 After pulling the pinna backward, the nurse inserted IRTT into the external auditory meatus.

119 The probe was held in the same position until the "beep" was heard. Temperature readings

120 were taken by the same trained nurse in the following order: forehead, forehead (the second

121 time), left wrist, right wrist, left tympanic, and right tympanic. The data were recorded by

122 another researcher in pre-printed files. Tympanic membrane is in close proximity to the

123 hypothalamus and the internal carotid artery (10). Thus, tympanic temperature is considered

124 to directly reflect core temperature (11), and was defined as the gold standard in this study.

125 These thermometers were stabilized before measurements. Calibration of thermometers were

126 checked by the Quality and Technology Supervision Bureau, Ningbo, China. It was

127 according to Calibration Specification of Infrared Thermometers for Measurement of Human

128 Temperature (JJF1107-2003).

130 Statistical analysis

131 Power calculation was performed for sample size. The following parameters were used: a

132 power of $90 \%$, an $\alpha$-error level of 0.05 , estimating a standard deviation of $1^{\circ} \mathrm{C}$ and a potential

133 allowable error of $0.2^{\circ} \mathrm{C}$. Considering a $10 \%$ possibility of dropouts and otherwise missing 134 data, at least 293 subjects were needed in our study. 
medRxiv preprint doi: https://doi.org/10.1101/2020.03.02.20030148; this version posted March 6, 2020. The copyright holder for this preprint

(which was not certified by peer review) is the author/funder, who has granted medRxiv a license to display the preprint in perpetuity.

All rights reserved. No reuse allowed without permission.

135 Continuous variables were expressed as mean \pm standard deviation (SD), and categorical

136 data in frequency and proportion. The agreements for each method versus

137 tympanic temperature were analyzed by Bland-Altman analysis (12). It also showed three

138 superimposed horizontal lines. Red dashed line highlighted mean bias among all the paired

139 measurements. Black dashed line marked upper and lower 95\% Limits of Agreement (LoA).

140 A temperature deviation of $0.5^{\circ} \mathrm{C}$ was considered as clinically acceptable (13). A tympanic

141 temperature of $\geq 37.3^{\circ} \mathrm{C}$ was defined as the cut-off point for fever. Statistical analyses were

142 conducted using $\mathrm{R}$ version 3.5.1 (The R Foundation for Statistical Computing, Vienna,

143 Austria).

144

145 
medRxiv preprint doi: https://doi.org/10.1101/2020.03.02.20030148; this version posted March 6, 2020. The copyright holder for this preprint

\section{Results}

\section{Participants}

148 In this prospective observational study, a total of 528 participants were enrolled. Figure 1

149 summarizes characteristics of the participants. The mean age was $46.7 \pm 16.4$ years. $69.4 \%$ ( $n$

$150=297)$ of participants were males, and 78.2\% $(n=413)$ were patients (Table 1). Mean

151 forehead, wrist, tympanic measurements were $35.6 \pm 1.2^{\circ} \mathrm{C}, 35.7 \pm 0.8^{\circ} \mathrm{C}$, and $36.6 \pm 0.6^{\circ} \mathrm{C}$,

152 respectively. There were 44 patients with fever in indoor patients. The data of outdoor 153 participants were collected on February 14th, 15th, 17th, 2020. Mean weather temperatures 154 were $13^{\circ} \mathrm{C}, 14^{\circ} \mathrm{C}$, and $7^{\circ} \mathrm{C}$, respectively.

\section{Bland-Altman comparison among the participants under different environment}

Table 2 showed mean temperatures and Bland-Altman analysis among the participants under different environment. Compared with tympanic temperature as golden standard, the mean difference ranged from -1.72 to $-0.56^{\circ} \mathrm{C}$ for the forehead measurement, and -0.96 to $-0.61^{\circ} \mathrm{C}$ for the wrist measurement. We observed a lower variation in wrist than forehead temperature measurements.

162 Outdoor participants were divided into four types as walk, bicycle or electric vehicle, car, 163 and inside the car. For those who walked, the agreement limits for wrist and tympanic was 164 between -2.05 and $0.34^{\circ} \mathrm{C} ;-4.07$ and $0.64^{\circ} \mathrm{C}$ for forehead and tympanic (Figure 2A, B). For 165 those who used bicycle or electric vehicle, the agreement limits for wrist and tympanic was 166 between -2.14 and $0.93^{\circ} \mathrm{C} ;-3.82$ and $0.84^{\circ} \mathrm{C}$ for forehead and tympanic (Figure 2C, D). For 167 those who were transported by car, the agreement limits for wrist and tympanic was between $168-1.43$ and $-0.44^{\circ} \mathrm{C} ;-1.47$ and $-0.36^{\circ} \mathrm{C}$ for forehead and tympanic (Figure $2 \mathrm{E}, \mathrm{F}$ ). For those 169 who were inside the car, the agreement limits for wrist and tympanic was between -1.54 and $170-0.15^{\circ} \mathrm{C} ;-2.41$ and $0.16^{\circ} \mathrm{C}$ for forehead and tympanic (Figure $2 \mathrm{G}, \mathrm{H}$ ). It highlighted that wrist 
medRxiv preprint doi: https://doi.org/10.1101/2020.03.02.20030148; this version posted March 6, 2020. The copyright holder for this preprint

(which was not certified by peer review) is the author/funder, who has granted medRxiv a license to display the preprint in perpetuity.

All rights reserved. No reuse allowed without permission.

171 temperature had narrower 95\% limits of agreement than forehead. Wrist measurements had

172 the higher percentage of differences falling within $\pm 0.5^{\circ} \mathrm{C}$ than forehead measurements in

173 these four types.

174 For indoor patients, the agreement limits for wrist and tympanic was between -2.70 and

$175-0.77^{\circ} \mathrm{C} ;-1.91$ and $0.80^{\circ} \mathrm{C}$ for forehead and tympanic (Figure 3 ). $57.1 \%$ of forehead values

176 were included within $\pm 0.5^{\circ} \mathrm{C}$, followed by wrist values $(41.4 \%)$. We also explore the

177 agreement of left and right wrists (Figure S1). The mean bias is 0.00 . The agreement limits

178 for wrist and tympanic was between -0.74 and $0.74^{\circ} \mathrm{C}$. It showed good agreement between

179 right and left wrists.

180

181 The receiver-operator characteristic (ROC) curves for detection of fever

182 We performed a ROC curves in indoor patients for detecting tympanic temperature

$183 \geq 37.3^{\circ} \mathrm{C}$. Figure 4 shows the comparison between wrist and forehead measurements for

184 detection of fever. Both measurement had significantly great abilities of screening patients

185 for fever (wrist: AUC 0.790; 95\% CI: 0.725-0.854, $P<0.001$; forehead: AUC 0.816; 95\% CI:

$1860.757-0.876, P<0.0001)$. The cut-off value of wrist measurement for detecting tympanic

187 temperature $\geq 37.3^{\circ} \mathrm{C}$ was $36.2^{\circ} 3$ with a $86.4 \%$ sensitivity and a $67.0 \%$ specificity. And the

188 best threshold of forehead measurement was also $36.2^{\circ} 6$ with a $93.2 \%$ sensitivity and a $60.0 \%$

189 specificity.

190 
medRxiv preprint doi: https://doi.org/10.1101/2020.03.02.20030148; this version posted March 6, 2020. The copyright holder for this preprint

\section{Discussion}

192 In this prospective real-world study, we found that wrist temperature measurement is 193 more stable than forehead using NCIT under different circumstances in outdoor participants.

194 Both measurement had significantly great abilities of screening patients for fever in indoor 195 patients. The cut-off value for wrist and forehead temperature were both $36.2^{\circ} \mathrm{C}$. They 196 showed good sensitivity. It may assist for fever screening in the population, especially in the 197 outbreak of 2019 Novel Coronavirus (COVID-19). To our knowledge, this study was the first to explore the reliability and validity of wrist and forehead temperature measurement in mass screening.

Previous studies showed that axilla, rectal temperature were the gold standards in clinical 201 practice $(14,15)$. However, it was impractical for the large-scale screening. Timesaving and 202 less invasive tools were needed. IRTT and NCIT are being applied in the general population 203 during the epidemic. A lot of disposable plastic covers were consumed, which may increase the financial burden. In China, it cost 1-2 RMB (about 0.2 dollars) for per disposable plastic cover. Besides, indirect contacts increased the risk of cross infection. Forehead temperature was used for the widespread use of population screening using NCIT. However, it can be

207 affected by a person's physiological and environmental conditions $(8,16)$. The forehead 208 temperature value of 23 participants showed "low" in our study. This all happened on the 209 same day (February 17 th, 2020) with an outside temperature of $7^{\circ} \mathrm{C}$. Thus, we chose wrist 210 temperature as an alternative, especially in the winter when mass screening is needed. Wrist 211 measurement indicated peripheral temperature at $10 \mathrm{~cm}$ above the palmar side of the wrist. It

212 was within our expectation that wrist measurement readings attained was lower than

213 tympanic route. However, this area was covered by clothing all the time. It was less 214 influenced by environmental conditions. Our study showed it was more stable for participants 215 under different circumstance than forehead measurement. It is important for mass screen in 
216 the open air during the Outbreak of COVID-19. The ROC curves showed wrist and forehead

217 measurement had significantly great abilities of screening patients for fever. The cut-off

218 value of both measurement was $36.2^{\circ} \mathrm{C}$. It can be applied in clinical practice and assist to

219 improve the standardization of both practical use and performance.

220 The strengths of this study included its large sample size, and prospective design in the 221 real-world setting. There were several limitations. First, it is difficult to quantify the 222 physiological and environmental conditions. Second, only one brand of thermometer was 223 enrolled in this study. It was uncertain that it could be generalized to all brands of 224 thermometers in the market.

225 In conclusion, this study confirmed wrist measurement was more stable for participants 226 under different circumstance than forehead measurement. Both measurement had 227 significantly great fever screening abilities for indoor patients, and the cut-off value of both 228 measurements for fever was $36.2^{\circ} \mathrm{C}$. Further studies are needed to explore the validity and 229 accuracy of wrist temperature.

231 Guarantor of the article

232 Xiaoming Chen

\section{Specific author contributions}

235 Study concept and design: Ge Chen, Lei Xu, Xueqin Chen, and Xiaoming Chen; Acquisition 236 of data: Peijun Zheng, Xiaqing Hu, Guangli Dai, Lei Xu and Hongpeng Lu; Analysis and 237 interpretation of data: Jiarong Xie and Ge Chen. Drafting of the manuscript: Jiarong Xie and 238 Ge Chen. Study supervision: Lei Xu, Xueqin Chen, and Xiaoming Chen. 
241 all authors have seen and approved the manuscript.

\section{Acknowledgment}

244 The authors thank Jihong Zhang for sorting of data; Ximing Jiang, Ying Xin for acquisition

245 and sorting of data.

\section{Declaration of competing interest}

248 None.

\section{Funding Statement}

251 None.

\section{Data Availability Statement}

254 The data used to support the findings of this study are available from the corresponding 255 author (Xiaoming Chen). 
medRxiv preprint doi: https://doi.org/10.1101/2020.03.02.20030148; this version posted March 6, 2020. The copyright holder for this preprint

\section{References}

259 1. Zumla A, Hui DS, Azhar EI, Memish ZA, Maeurer M. Reducing mortality from 260 2019-nCoV: host-directed therapies should be an option. The Lancet 2020.

261 2. Wu JT, Leung K, Leung GM. Nowcasting and forecasting the potential domestic and 262 international spread of the 2019-nCoV outbreak originating in Wuhan, China: a modelling 263 study. The Lancet 2020.

264 3. Wang W, Tang J, Wei F. Updated understanding of the outbreak of 2019 novel 265 coronavirus (2019-nCoV) in Wuhan, China. Journal of Medical Virology 2020.

266 4. Wang D, Hu B, Hu C, Zhu F, Liu X, Zhang J, et al. Clinical characteristics of 138 267 hospitalized patients with 2019 novel coronavirus-infected pneumonia in Wuhan, China. 268 Jama 2020.

269 5. Guan W-j, Ni Z-y, Hu Y, Liang W-h, Ou C-q, He J-x, et al. Clinical characteristics of 2702019 novel coronavirus infection in China. medRxiv 2020.

271 6. Devrim I, Kara A, Ceyhan M, Tezer H, Uludag AK, Cengiz AB, et al. Measurement 272 accuracy of fever by tympanic and axillary thermometry. Pediatric emergency care $273 \quad 2007 ; 23: 16-19$.

274 7. Mogensen CB, Wittenhoff L, Fruerhøj G, Hansen S. Forehead or ear temperature 275 measurement cannot replace rectal measurements, except for screening purposes. BMC 276 pediatrics 2018;18:15.

277 8. Erenberk U, Torun E, Ozkaya E, Uzuner S, Demir AD, Dundaroz R. Skin temperature 278 measurement using an infrared thermometer on patients who have been exposed to cold. 279 Pediatrics International 2013;55:767-770.

280 9. Holt S, Yo J, Karschimkus C, Volpato F, Christov S, Smith E, et al. Monitoring skin 281 temperature at the wrist in hospitalised patients may assist in the detection of infection. 282 Internal Medicine Journal 2020.

283 10. Campbell I. Body temperature and its regulation. Anaesthesia \& Intensive Care Medicine $284 \quad 2008 ; 9: 259-263$.

285 11. Gasim GI, Musa IR, Abdien MT, Adam I. Accuracy of tympanic temperature 286 measurement using an infrared tympanic membrane thermometer. BMC research notes $287 \quad 2013 ; 6: 194$.

288 12. Bland JM, Altman DG. Measuring agreement in method comparison studies. Statistical 289 methods in medical research 1999;8:135-160. 
medRxiv preprint doi: https://doi.org/10.1101/2020.03.02.20030148; this version posted March 6, 2020. The copyright holder for this preprint (which was not certified by peer review) is the author/funder, who has granted medRxiv a license to display the preprint in perpetuity. All rights reserved. No reuse allowed without permission.

290 13. Suleman M-I, Doufas AG, Akça O, Ducharme M, Sessler DI. Insufficiency in a new 291 temporal-artery thermometer for adult and pediatric patients. Anesthesia \& Analgesia $292 \quad 2002 ; 95: 67-71$.

293 14. Berksoy E, Anıl M, Bıcılığlu Y, Gökalp G, Bal A. Comparison of infrared tympanic, 294 non-contact infrared skin, and axillary thermometer to rectal temperature measurements in a 295 pediatric emergency observation unit. Int J Clin Exp Med 2018;11:567-573.

296 15. Rabbani MZ, Amir M, Malik M, Mufti M, Bin Pervez M, Iftekhar S. Tympanic 297 temperature comparison with oral mercury thermometer readings in an OPD setting. J Coll 298 Physicians Surg Pak 2010;20:33-36.

299 16. Vesnovsky O, Li Y, Topoleski L, Zhu L. Modeling of Differences Between Body Core 300 and Forehead Temperatures Measured by Infrared Thermometers. In: 2017 Design of 301 Medical Devices Conference; 2017: American Society of Mechanical Engineers Digital 302 Collection; 2017. 


\section{Figure Legends}

306 Figure 1. Flowchart of the study.

308 Figure 2. Bland-Altman comparison between each method and tympanic temperature. X axis

309 is the mean temperature of each method and tympanic. Y axis is the difference of each

310 method and tympanic. Red dashed line showed mean bias. Black dashed lines showed 95\%

311 limits of agreement. (A), (B) for those who walked; (C), (D) for those who used

312 bicycle/electric vehicle; $(\mathrm{E}),(\mathrm{F})$ for those who were transported by car; $(\mathrm{G}),(\mathrm{H})$ for those

313 who were inside the car

315 Figure 3. Bland-Altman comparison between each method and tympanic temperature for

316 indoor patients. $\mathrm{X}$ axis is the mean temperature of each method and tympanic. $\mathrm{Y}$ axis is the

317 difference of each method and tympanic. Red dashed line showed mean bias. Black dashed

318 lines showed $95 \%$ limits of agreement.

320 Figure 4. The receiver-operator characteristic (ROC) curves for detection of fever. 
medRxiv preprint doi: https://doi.org/10.1101/2020.03.02.20030148; this version posted March 6, 2020. The copyright holder for this preprint

(which was not certified by peer review) is the author/funder, who has granted medRxiv a license to display the preprint in perpetuity.

All rights reserved. No reuse allowed without permission.

322 Table 1. Demographic characteristics of the participants

\begin{tabular}{ll}
\hline Variables & Total $(n=528)$ \\
\hline Age, years & $46.7 \pm 16.4$ \\
Gender, male, $\mathrm{n}(\%)$ & $297(69.4 \%)$ \\
Environment & \\
$\quad$ Indoor patients, $\mathrm{n}(\%)$ & $261(49.4 \%)$ \\
$\quad$ Walk, $\mathrm{n}(\%)$ & $120(22.7 \%)$ \\
$\quad$ Bicycle/Electric vehicle, $\mathrm{n}(\%)$ & $39(7.4 \%)$ \\
$\quad$ Transported by car, $\mathrm{n}(\%)$ & $56(10.6 \%)$ \\
$\quad$ Inside the car, $n(\%)$ & $52(9.8 \%)$ \\
Patients or not & \\
$\quad$ Yes, $n(\%)$ & $413(78.2 \%)$ \\
Forehead temperature, ${ }^{\circ} \mathrm{C}$ & $35.6 \pm 1.2$ \\
Wrist temperature, ${ }^{\circ} \mathrm{C}$ & $35.7 \pm 0.8$ \\
Tympanic temperature, ${ }^{\circ} \mathrm{C}$ & $36.6 \pm 0.6$ \\
\hline
\end{tabular}

323

324 
medRxiv preprint doi: https://doi.org/10.1101/2020.03.02.20030148; this version posted March 6, 2020. The copyright holder for this preprint (which was not certified by peer review) is the author/funder, who has granted medRxiv a license to display the preprint in perpetuity.

All rights reserved. No reuse allowed without permission.

325 Table 2. Bland-Altman comparison among the participants under different environment

\begin{tabular}{|c|c|c|c|c|c|}
\hline \multirow[t]{2}{*}{ Environment } & \multirow[t]{2}{*}{ Method } & \multirow{2}{*}{$\begin{array}{l}\text { Mean } \\
\text { temperature }\left({ }^{\circ} \mathrm{C}\right)\end{array}$} & \multicolumn{3}{|c|}{ Bland-Altman comparison $\left({ }^{\circ} \mathrm{C}\right)$} \\
\hline & & & Mean difference & $95 \%$ prediction interval & Proportion of Differences within $0.5^{\circ} \mathrm{C}$ \\
\hline \multirow[t]{3}{*}{ Indoor patients } & Tympanic & 36.8 & reference & & \\
\hline & Wrist & 35.8 & -0.96 & $(-2.70-0.77)$ & $41.4 \%$ \\
\hline & Forehead & 36.2 & -0.56 & $(-1.91-0.80)$ & $57.1 \%$ \\
\hline \multirow[t]{3}{*}{ Walk } & Tympanic & 36.3 & reference & & \\
\hline & Wrist & 35.4 & -0.86 & $(-2.05-0.34)$ & $72.5 \%$ \\
\hline & Forehead & 34.6 & -1.72 & $(-4.07-0.64)$ & $22.5 \%$ \\
\hline Bicycle/Electric & Tympanic & 36.0 & reference & & \\
\hline \multirow[t]{2}{*}{ vehicle } & Wrist & 35.5 & -0.61 & $(-2.14-0.93)$ & $56.4 \%$ \\
\hline & Forehead & 34.6 & -1.49 & $(-3.82-0.84)$ & $48.7 \%$ \\
\hline Transported by & Tympanic & 36.6 & reference & & \\
\hline \multirow[t]{2}{*}{ car } & Wrist & 35.7 & -0.93 & $(-1.43--0.44)$ & $91.1 \%$ \\
\hline & Forehead & 35.4 & -0.92 & $(-1.47--0.36)$ & $85.7 \%$ \\
\hline \multirow[t]{3}{*}{ Inside the car } & Tympanic & 36.7 & reference & & \\
\hline & Wrist & 35.8 & -0.85 & $(-1.54--0.15)$ & $94.2 \%$ \\
\hline & Forehead & 35.8 & -1.13 & $(-2.41-0.16)$ & $80.8 \%$ \\
\hline
\end{tabular}

326 
medRxiv preprint doi: https://doi.org/10.1101/2020.03.02.20030148; this version posted March 6, 2020. The copyright holder for this preprint (which was not certified by peer review) is the author/funder, who has granted medRxiv a license to display the preprint in perpetuity.

All rights reserved. No reuse allowed without permission.

All participants $(n=572)$

Excluded $(n=43)$ :

1. Age $\leq 18$ years $(n=6)$;

2. Wearing hearing aid, or having a cerumen $(\mathrm{n}=7)$;

3. Participants with soft tissue infection or trauma $(\mathrm{n}=3)$; 4.Missing data of wrist, forehead, and tympanic temperature $(n=4)$;

5. Participants whose forehead temperature measurements showed "low" $(\mathrm{n}=23)$;

Eligible participants $(n=528)$

According to different location

Outdoor participants $(n=267)$

Indoor patients $(n=261)$

According to different transportation

Walk $(n-120)$

Bicycle/Electric vehicle $(n=39)$

Transported by car $(n=56)$

Inside the car $(n=52)$ 
(A) Walk: forehead - tympanic
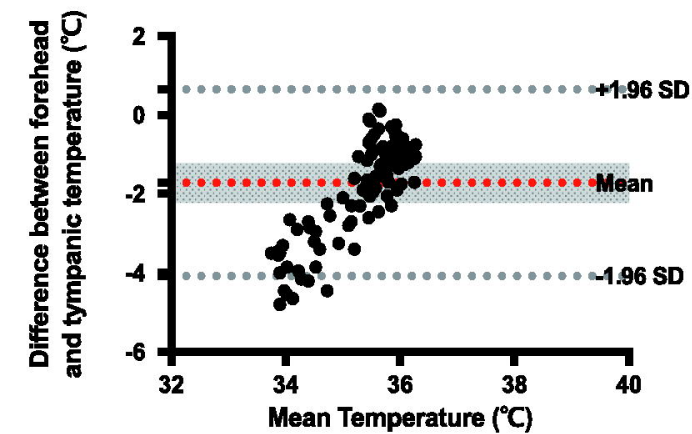

(C) Bicycle/Electric vehicle: forehead - tympanic
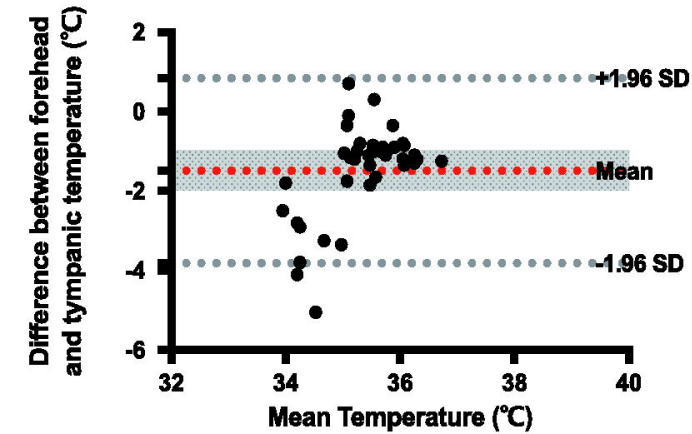

(E) Inside the car: forehead - tympanic
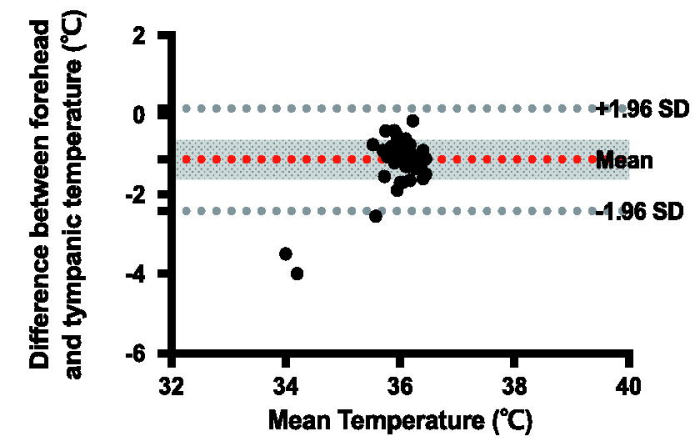

(G) Transported by car: forehead - tympanic
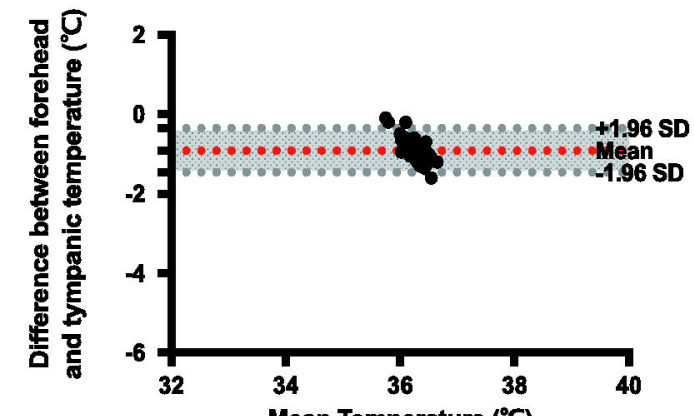

(B) Walk: wrist - tympanic

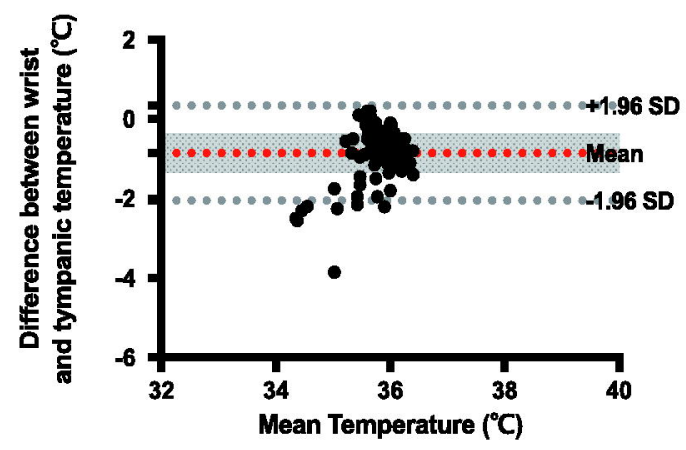

(D) Bicycle/Electric vehicle: wrist - tympanic

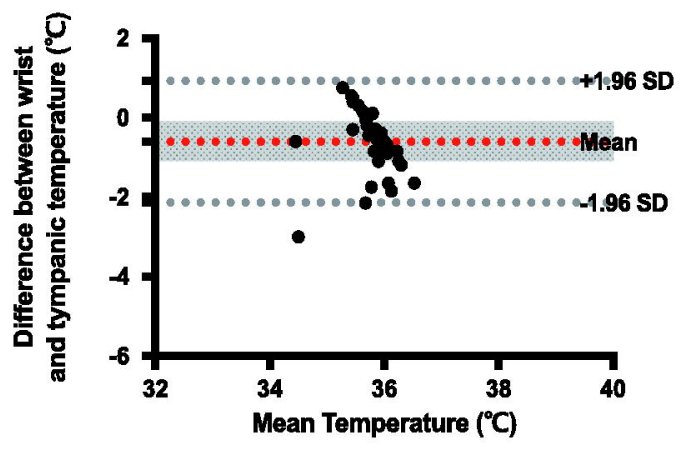

(F) Inside the car: wrist - tympanic

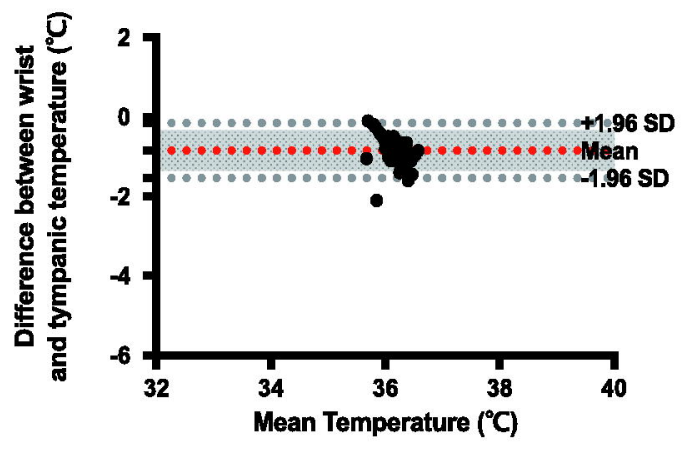

(H) Transported by car: wrist - tympanic

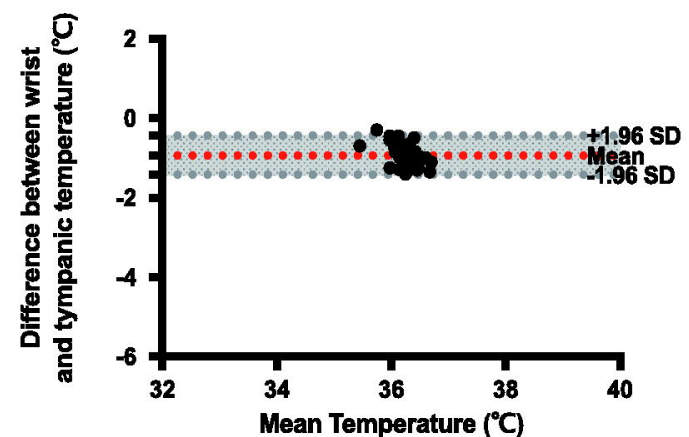


medRxiv preprint doi: https://doi.org/10.1101/2020.03.02.20030148; this version posted March 6, 2020. The copyright holder for this preprint (which was not certified by peer review) is the author/funder, who has granted medRxiv a license to display the preprint in perpetuity.

All rights reserved. No reuse allowed without permission.

(A) Indoor patients: forehead - tympanic

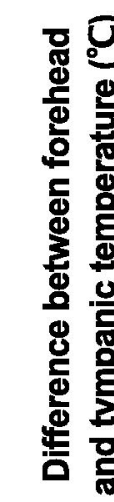

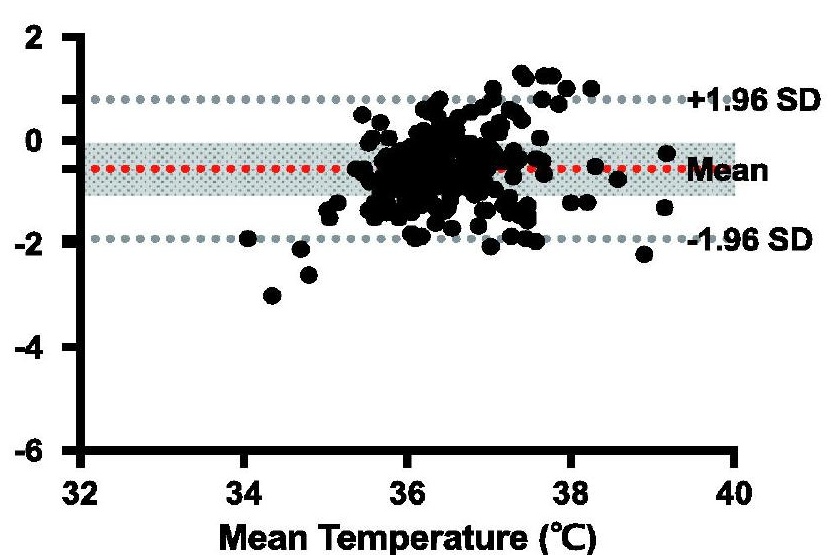

(B) Indoor patients: wrist - tympanic

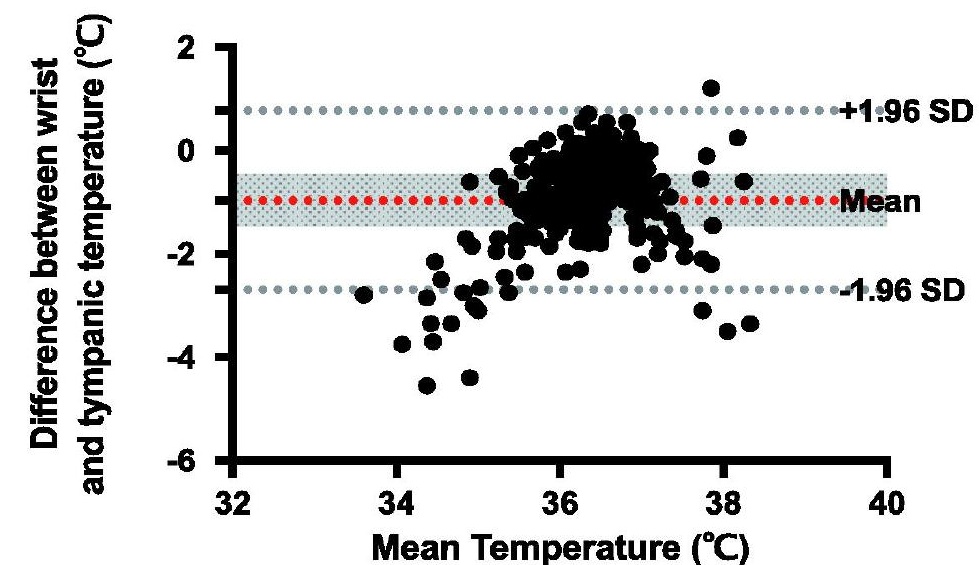


medRxiv preprint doi: https://doi.org/10.1101/2020.03.02.20030148; this version posted March 6, 2020. The copyright holder for this preprint (which was not certified by peer review) is the author/funder, who has granted medRxiv a license to display the preprint in perpetuity.

All rights reserved. No reuse allowed without permission.

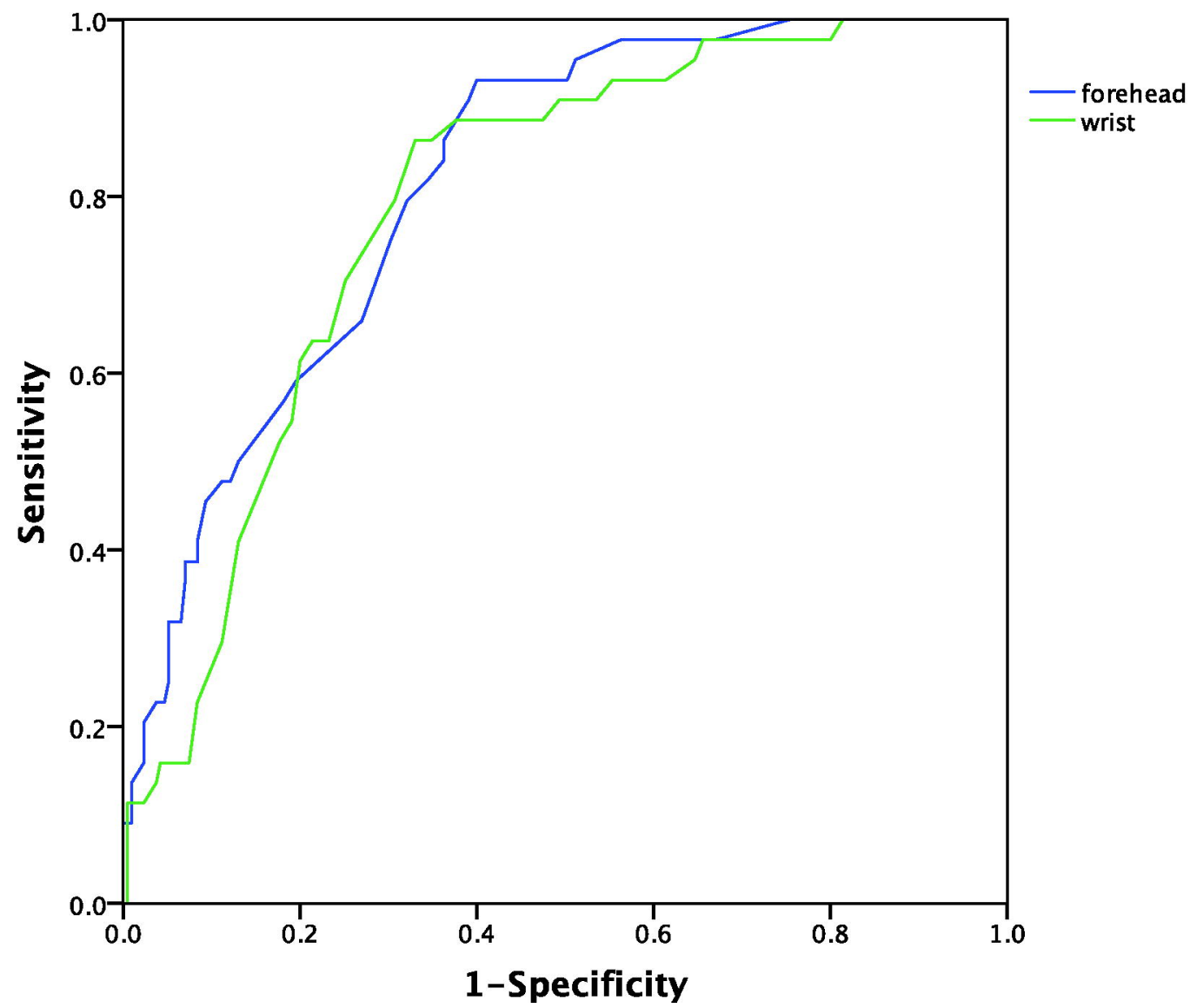

